ISSN: $1896-4087$

DOI: http://dx.doi.org/10.21784/ZC.2016.026

ARKADIUSZ JĄKALSKI

Uniwersytet Mikołaja Kopernika w Toruniu

\title{
Tworzenie spółek wodnych w świetle aktualnych regulacji prawnych
}

\section{Creating water companies in light of current legal regulations}

\section{Streszczenie:}

Gospodarka wodna jest nieodłącznym elementem życia i rozwoju nowoczesnych społeczeństw. Nieodłącznym elementem tej gospodarki są spółki wodne. W Polsce zagadnienia te są uregulowane w odpowiednich przepisach, a ich podstawę stanowi ustawa z dnia 18 lipca 2001r. prawo wodne .

Spółki wodne jako forma działalności organizacyjnej, zostały ujęte już w ustawie prawo wodne z 1922r. Mają one więc swoje prawne umocowania od wielu lat. Znalazło to swoje odzwierciedlenie w prawie wodnym z $2001 \mathrm{r}$. W myśl przepisów tam zawartych urządzenia melioracyjne służące do nawadniania lub odwadniania gruntów utrzymywane są przez właścicieli gruntów lub inne podmioty, które odnoszą z tego tytuły korzyści. Dlatego dla usprawnienia i ulepszenia realizacji właściwego gospodarowania wodami i urządzeniami wodnymi przez właścicieli gruntów i wszystkich odnoszących korzyści tworzone są dobrowolne organizacje zwane spółkami wodnymi, które przejmują wykonywanie obowiązków związanych z utrzymywaniem urządzeń melioracji szczegółowych od zainteresowanych.

Słowa kluczowe: spółka wodna, zarząd spółki, prawo wodne, komisja rewizyjna, katastrat. 
Arkadiusz Jąkalski - Tworzenie spółek wodnych...

\begin{abstract}
:
Water economy is an inseparable part of life and modern societies development. An inseparable part of the water economy are water companies. In Poland such issues are organized by proper regulations and their basis is a legal act set up on the 18th of July, 2001, called Water Law.

Water companies as a form of organized activity has been implemented in legal act Water Law since 1922 thus having been fixed for many years. It was reflected in in the Water Law in 2001. According to the legal regulations in the Water Law, the devices used for irrigation and desiccation of the arable lands are maintained by the land owners and other business entities who benefit from the usage of these lands. Therefore, for the improvement of the usage of water and water devices by land owners and other entities, voluntary organizations called water companies are set up. Water companies take over the responsibilities concerned with the land improvement from the people concerned.
\end{abstract}

Keywords: water company, company board, Water Law, audit committee, katastrat

\title{
Cel i przedmiot opracowania
}

Spółka wodna jest swoistego rodzaju umową mającą na celu zaspokajanie wskazanych ustawą - prawo wodne - potrzeb z zakresu gospodarowania wodami. Spółka wodna jest formą organizacyjną odrębną zarówno od spółek cywilnych działających w oparciu o ustawę z dnia 23 kwietnia 1964 r. - Kodeks cywilny, jak i od spółek prawa handlowego, osobowych i kapitałowych, działających w oparciu o ustawę z dnia 15 września 2000 r. - Kodeks spółek handlowych. Jej powstanie i zasady działania reguluje wspomniana już wcześniej ustawa - prawo wodne1.

W polskim systemie prawnym funkcjonują różne typy spółek. Spółki wodne są typowym przykładem spółek prawa administracyj-

\footnotetext{
${ }^{1}$ D. Pikor, Tworzenie spółek wodnych, http://www.naukaibiznes.tv/artykuly/po kaz/tworzenie-spolek-wodnych (dostęp: 10.03.2016 r.).
} 
nego ${ }^{2}$. Spółka wodna to instytucja prawnoustrojowa, podlegająca przepisom prawa wodnego, która daje podstawę do wykorzystania działań i inicjatyw społecznych do wykonywania zadań administracji publicznej w dziedzinie gospodarki wodnej ${ }^{3}$. Uwzględniając poglądy piśmiennictwa, a przede wszystkim treść przepisu art. 164 ust. 1 ustawy prawo wodne, można przyjąć, że spółka wodna to podmiot prawa o charakterze publicznoprawnym, związany z gospodarką wodną4.

Spółka prawa administracyjnego jest organizacją bardzo specyficzną, zrzeszającą osoby fizyczne lub prawne powołaną po to, aby nadzorować wspólne przedsięwzięcia. Zalicza się do nich na przykład spółki powołane do zarządzania wspólnotami gruntowymi uregulowane w art. 14-25 ustawy z dnia 29 czerwca 1963r. o zagospodarowaniu wspólnot gruntowych ${ }^{5}$ oraz spółki wodne, uregulowane w ustawie prawo wodne 6 .

Celem opracowania jest przede wszystkim analiza zasad i mechanizmów jakie towarzyszą powstawaniu spółek wodnych.

\section{Powstanie spółki wodnej}

Ustawodawca w bardzo skromny sposób uregulował kwestie związane z powstaniem i funkcjonowaniem spółek wodnych, nie przyznając żadnym organom delegacji do wydania jakichkolwiek przepisów wykonawczych. Rodzi się więc pytanie o możliwość posługiwania się, w kwestiach w ustawie nieuregulowanych, przepisami dotyczącymi innych rodzajów spółek. Lakoniczność ustawodawcy w sprawach spółek wodnych sugeruje możliwość swobodnego kształtowania stosunków wewnątrz tych spółek celem dostosowania ich organizacji do zadań, które mają realizować w celu zaspakajania potrzeb członków

\footnotetext{
2 B. Rakoczy, Wybrane problemy prawa wodnego, Warszawa 2013, s. 245.

${ }^{3}$ R. Paczuski, Spótki wodne - cele, zadania, prawne podstawy organizacji oraz perspektywy ich rozwoju w kontekście zachodzacych zmian, Toruń 2006, s. 9 i nast.

4 B. Rakoczy, Prawo wodne komentarz, Warszawa 2013, s. 678.

5 T.j. Dz. U. z 1963r. Nr 28, poz. 169 z późn. zm.

6 J. Szałuchowicz, Prawo wodne. Komentarz, Warszawa 2010, s. 404.
} 
Arkadiusz Jąkalski - Tworzenie spółek wodnych...

z zakresu gospodarowania wodami. Nie ma więc przeszkód w stosowaniu przez spółki wodne rozwiązań przyjętych dla spółek innego rodzaju, o ile rozwiązania te zostaną przyjęte przez właściwe organy spółki. Pamiętać jedynie należy, że rozwiązania takie nie mogą być spółce narzucone z zewnątrz, a w szczególności przez organy uprawnione do kontrolowania spółek wodnych7\%.

Do powstania spółki wodnej potrzebne jest porozumienie co najmniej 3 osób fizycznych lub prawnych. Inicjatorem powstania takiej spółki nie może być jednostka organizacyjna nie posiadająca osobowości prawnej. Dla zawarcia porozumienia nie jest konieczna forma aktu notarialnego. Jednocześnie ustawodawca wyraźnie wskazuje, że porozumienie w sprawie powołania spółki wodnej powinno być sporządzone na piśmie. Porozumienie jest dokumentem prywatnym, niewymagającym zatwierdzenia przez żadną władzę, ani koniecznym do okazywania żadnej władzy, gdyż ustawodawca nie nałożył takich wymogów na osoby działające w celu powołania spółki wodnej8 ${ }^{8}$.

Spółki wodne zgodnie $\mathrm{z}$ art. 164 ust. 8 ustawy prawo wodne, mogą tworzyć związki spółek wodnych, które są szerszą struktura organizacyjną. Natomiast zgodnie z art. 164 ust. 10 wyżej wymienionej ustawy, mogą również być powoływane związki wałowe, których celem jest wykonanie i utrzymywanie wałów przeciwpowodziowych wraz z urządzeniami wodnymi stanowiącymi ich wyposażenie. Dla związków wałowych stosuje na podstawie art. 164 ust. 11 ustawy prawo wodne odpowiednie przepisy dotyczące spółek wodnych. Jednak w przeciwieństwie do spółek wodnych nadzór nad ich działalnością sprawuje właściwy marszałek województwa zgodnie z art. 164 ust. 9 Prawa wodnego.

Do utworzenia spółki konieczne jest uchwalenie statutu przez osoby zainteresowane utworzeniem spółki i dokonanie wyboru władz. Spółka wodna nabywa osobowość prawną z chwilą zatwierdzenia statutu przez starostę. Utworzenie spółki podlega obowiązkowi wpisu

\footnotetext{
7 D. Pikor, op.cit.

8 Ibid.
} 
w katastrze wodnym (odpowiednik KRS lub CEIDG) zgodnie z art. 167 ustawy prawo wodne.

Stosownie do art. 165 ust. 1 prawa wodnego do utworzenia spółki wodnej wymagane jest podjęcie następujących czynności:

1) uchwalenie statutu spółki przez osoby zainteresowane utworzeniem spółki,

2) dokonanie wyboru organów spółki.

\section{Statut spółki}

Statut spółki, oprócz przepisów prawa wodnego, jest podstawowym dokumentem, regulującym powstanie, ustrój i ustanie spółki jako osoby prawnej. Statut spółki powinien być uchwalony przez osoby zainteresowane utworzeniem spółki. Prawo wodne przewiduje dla przyjęcia statutu formę uchwały nie wskazuje większości, która jest potrzebna do jej podjęcia. Uchwały walnego zgromadzenia spółki w sprawie zmiany statutu wymagają większości $2 / 3$ głosów przy obecności, co najmniej połowy członków spółki. Zasadnym w tej sytuacji wydaje się przyjęcie, że skoro zmiana statutu nie wymaga jednomyślnej uchwały i wystarczająca jest do jej przyjęcia większość kwalifikowana 2/3 głosów, to do podjęcia uchwały uchwalającej statut taka większość, spośród osób, które zawarły porozumienie w sprawie utworzenia spółki, też będzie wystarczająca, zwłaszcza w sytuacji, gdy porozumienie uzależnia członkostwo w spółce od jego podpisania9. Do statutu dołącza się wykaz członków spółki, zawierający ich oznaczenie, wskazanie ich siedzib i adresów. Statut spółki wodnej podlega zatwierdzeniu przez Starostę właściwego miejscowo dla siedziby spółki wodnej. Spółka wodna nabywa osobowość prawną z chwilą uprawomocnienia się decyzji starosty o zatwierdzeniu statutu.

Osoby zainteresowane utworzeniem spółki wodnej opracowują statut, zgodnie wymaganiami określonymi w art. 166 ust. 1 prawa

\footnotetext{
${ }^{9}$ Ł. Opaliński, Melioracje - aspekty prawne -opracowanie, Wrocław 2013, s. 1-3.
} 
Arkadiusz Jąkalski - Tworzenie spółek wodnych...

wodnego. Statut spółki wodnej musi zawierać takie elementy obowiązkowe jak:

1) nazwę i siedzibę spółki oraz teren jej działalności,

2) cel spółki oraz sposób i środki służące do osiągnięcia tego celu,

3) zasady ustalania wysokości składek i innych świadczeń na rzecz spółki, adekwatnych do celów spółki,

4) zasady ustalania należności za dostarczanie wody oraz odprowadzanie i oczyszczanie ścieków, w przypadku prowadzenia działalności, o której mowa w art. 164 ust. 2,

5) prawa i obowiązki członków spółki,

6) ograniczenia praw członków dotyczące ich gruntów i obiektów niezbędnych do wykonywania zadań spółki, warunki przyjmowania nowych członków oraz wykluczania członków ze spółki,

7) warunki następstwa prawnego członków spółki,

8) organy spółki, ich skład, zasady powoływania i odwoływania oraz zakres działania,

9) zasady nawiązywania stosunku pracy w ramach spółki,

10) przypadki wymagające zwołania walnego zgromadzenia,

11) czas trwania spółki oraz sposób jej rozwiązania lub likwidacji,

12) warunki zaciągania zobowiązań i udzielania pełnomocnictw do reprezentowania spółki,

13) przeznaczenie mienia pozostałego po rozwiązaniu lub likwidacji spółki.

Są to minimalne wymogi jakie muszą wystąpić w każdym prawidłowym statucie spółki wodnej. Nie oznacza to jednak, że nie można w nim zawrzeć więcej regulacji. Zgodnie ze stanowiskiem Sądu Najwyższego z dnia 29 czerwca 2010 r.10 uznano, że statut spółki wodnej nie może ograniczać uprawnienia członka do wystąpienia ze spółki również, gdy jego członkostwo powstało ex lege na podstawie art. 165 ust. 7 prawa wodnego. Oprócz tego koniecznym elementem każdego statutu spółki wodnej jest wykaz członków spółki, zawierający ich

10 Sygnatura akt III CZP/46/10 (OSNC 2011, nr 2, poz.18). 
oznaczenie, wskazanie ich siedzib i adresów zgodnie z art. 166 ust. 2 prawa wodnego.

\section{Organy spółki}

Kolejną czynnością niezbędną dla utworzenia spółki jest dokonanie wyboru jej organów. Wybór organów spółki następuje po uchwaleniu jej statutu, albowiem to statut przewiduje jakie organy i o jakim składzie będzie posiadać spółka, a także w jaki sposób będą one powoływane. Ustawodawca dla czynności wyboru organów nie wymaga podjęcia uchwały, ponieważ to, czy uchwała taka będzie konieczna, uzależnione jest od organu, któremu uprawnienie do powoływania określonego organu spółki zostanie przyznane w statucie. Jeżeli w uchwalonym przez członków założycieli statucie uprawnienie do powoływania członków organów przyznane zostanie komuś innemu niż organ kolegialny, powołanie to nie nastąpi w formie uchwały. Wybór organów powinien być potwierdzony na piśmie ${ }^{11}$.

Spółka może być utworzona dla potrzeb jednej lub kilku wsi, albo całej gminy. W skład spółki wodnej mogą wchodzić także: gminy, zakłady i itp. Spółki wodne mogą łączyć się w związki spółek wodnych, do których stosuje się odpowiednio przepisy dotyczące spółek wodnych, z tym że prawa i obowiązki przysługujące wobec spółek wodnych staroście, w stosunku do związków spółek wodnych wykonuje marszałek województwa.

Spółki wodne, zapewniając zaspokojenie potrzeb zrzeszonych w nich osób w dziedzinie gospodarowania wodami, mogą podejmować działalność umożliwiającą osiągnięcie zysku netto. Osiągnięty zysk netto przeznacza się wyłącznie na cele statutowe spółki wodnej na podstawie art. 164 ust.2 ustawy prawo wodne.

\footnotetext{
11 www.srodowisko.abc.com.pl/czytaj/-/artykul/tworzenie-spolek-wodnych (dostęp: 10.03.2016 r.).
} 
Arkadiusz Jąkalski - Tworzenie spółek wodnych...

Spółka wodna działa poprzez wybrane przez siebie organy. Zgodnie z przepisami art. 172 ust. 1 ustawy prawo wodne organami spółki wodnej są:

1) walne zgromadzenie - należy tutaj zauważyć, że ustawodawca w przypadku tego organu dopuszcza możliwość zastąpienia walnego zgromadzenia członków spółki wodnej walnym zgromadzeniem delegatów. W praktyce oznacza to, że wszystkie sprawy związane z wyborem władz, udzielaniem absolutorium zarządowi spółki, itp. zostają powierzone przez członków spółki wybranym delegatom ${ }^{12}$.

2) zarząd,

3) komisja rewizyjna, o ile spółka liczy więcej niż dziesięciu członków.

Pierwsze dwa organy są instytucjami obligatoryjnymi dla prawidłowego funkcjonowania spółki wodnej. Istnienie komisji rewizyjnej jest uzależnione od liczby członków spółki wodnej. Jeśli jest ich co najmniej dziesięciu powołanie komisji rewizyjnej jest obowiązkowe. Oprócz tego w spółce wodnej, związkach spółek lub związkach wałowych mogą istnieć również inne organy, jednak ich istnienie i funkcjonowanie jest uzależnione wyłącznie od zapisów statutowych danej spółki13.

Najważniejszym organem spółki wodnej jest walne zgromadzenie delegatów. Do kompetencji walnego zgromadzenia zgodnie z art. 173 ust. 1 omawianej ustawy należy:

1) uchwalanie planu prac spółki wodnej oraz jej budżetu, w którym można upoważnić zarząd do zaciągania pożyczek lub kredytów, w imieniu spółki, do ustalonej wysokości,

2) uchwalania wysokości składek i innych świadczeń na rzecz spół$\mathrm{ki}$,

3) ustalanie wysokości należności za dostarczanie wody oraz odprowadzanie i oczyszczanie ścieków, w przypadku prowadzenia

\footnotetext{
12 Statut Gminnej Spółki Wodnej „Topólka” w Topólce, Rozdział V § 19.

13 B. Rakoczy, Prawo..., op. cit., s. 698.
} 
działalności, o której mowa w art. 164 ust. 2 wspomnianej wyżej ustawy,

4) wybór oraz odwołanie członków zarządu i członków komisji rewizyjnej,

5) rozpatrywanie i zatwierdzanie rocznych sprawozdań oraz udzielanie zarządowi absolutorium,

6) podejmowanie uchwał $w$ sprawie nabycia nieruchomości albo zbycia lub obciążenia nieruchomości spółki wodnej,

7) uchwalanie zmian statutu spółki wodnej,

8) podejmowanie uchwał w sprawie przystąpienia spółki wodnej do związku spółek wodnych,

9) podejmowanie uchwał $w$ sprawie połączenia spółki wodnej z inną spółką wodną albo podziału spółki wodnej na dwie lub więcej spółek,

10) podjęcie uchwały w sprawie rozwiązania spółki wodnej oraz powołania likwidatorów,

11) zatwierdzanie ostatecznych rachunków i sprawozdań likwidatora spółki wodnej,

12) podejmowanie uchwał w sprawach przedstawionych przez zarząd lub komisję rewizyjną.

Powyższe kompetencje są zastrzeżone tylko dla instytucji walnego zgromadzenia. Katalog ten ma charakter zamknięty. Walne zgromadzenie zgodnie $\mathrm{z}$ art. 174 prawa wodnego jest zwoływane przez zarząd co najmniej raz w roku ${ }^{14}$.

Zarząd spółki wodnej jest organem wykonawczym spółki. Na podstawie art. 176 prawa wodnego do zadań zarządu należy:

1) wykonanie uchwał walnego zgromadzenia,

2) kierowanie działalnością spółki,

3) zarządzanie jej majątkiem,

4) prowadzenie gospodarki finansowej

14 Ibid., s. 700. 
Arkadiusz Jąkalski - Tworzenie spółek wodnych...

5) reprezentowanie spółki na zewnątrz - przy czym do reprezentowania (składania oświadczeń woli) zgodnie z art. 176 ust. 1 jeśli statut nie stanowi inaczej uprawniony jest:

a) jeden członek zarządu jeśli w skład zarządu wchodzą nie więcej niż 2 osoby,

b) dwóch członków zarządu w pozostałych przypadkach.

Zarząd, jak już wspomniano wyżej może być jednoosobowy lub wieloosobowy. Liczbę członków zarządu określa statut spółki. Zarząd wybierany jest na 5 lat, jeżeli statut spółki wodnej nie stanowi inaczej. Do właściwości zarządu należą sprawy niezastrzeżone dla innych organów spółki. Zarząd spółki wodnej ma prawo obciążania członków spółki kosztami świadczeń lub prac niewykonanych w terminie.

\section{Wpis do katastratu wodnego}

Zarząd spółki wodnej oprócz wymienionych wyżej czynności zgłasza utworzenie spółki w celu wpisania do katastru wodnego, prowadzonego przez Regionalny Zarząd Gospodarki Wodnej w Warszawie, w terminie 30 dni od dnia nabycia przez spółkę osobowości prawnej. Wpis spółki wodnej do katastru wodnego obejmuje:

1) nazwę, siedzibę, adres i przedmiot działania spółki,

2) imiona i nazwiska członków zarządu oraz sposób reprezentowania spółki,

3) czas trwania spółki,

4) dane dotyczące decyzji starosty o zatwierdzeniu statutu.

Wypis z katastru wodnego stanowi dokument potwierdzający osobowość prawną spółki. Nie dopełnienie przez zarząd spółki obowiązku zgłoszenia spółki do katastru wodnego, w świetle art. 194 Prawa wodnego, stanowi wykroczenie zagrożone karą grzywny, orzekaną 
przez sądy ${ }^{15} \mathrm{w}$ trybie ustawy z dnia 24 sierpnia 2001 r. - Kodeks postępowania w sprawach o wykroczeniach ${ }^{16}$.

\section{Inne czynności towarzyszące tworzeniu spółki}

Oprócz tego do czynności organizacyjnych zarządu, na etapie tworzenia spółki wodnej, należą

1) zgłoszenie do Urzędu Statystycznego celem nadania numeru REGON,

2) zgłoszenie do Urzędu Skarbowego celem nadania numeru NIP,

3) założenie konta bankowego,

4) wyrobienie odpowiednich pieczątek,

5) przygotowanie mapy obszaru działalności Spółki Wodnej z zaznaczonymi urządzeniami i budowlami melioracji wodnych szczegółowych,

6) sporządzenie wykazu urządzeń i budowli melioracji szczegółowych dla Wojewódzkiego Zarządu Melioracji i Urządzeń Wodnych ${ }^{17}$.

Zgodnie z art. 173 ust. 2 Prawa wodnego praca zarządu podlega ocenie przez walne zgromadzenie. Dla tego w trakcie obrad tego organu po zakończeniu danego roku kalendarzowego walne zgromadzenie podejmuje uchwałę o udzieleniu lub nieudzieleniu absolutorium zarządowi spółki wodnej przez walne zgromadzenie. Jest ono równoznaczne $\mathrm{z}$ odwołaniem zarządu. W efekcie nieudzielenia zarządowi absolutorium cały zarząd zostaje odwołany. Nie ma tutaj mowy o odwoływaniu pojedynczych jego członków, na co wyraźnie wskazuje zapis omawianego powyżej artykułu, który zawiera sformułowanie „zarząd spółki” a nie „członek zarządu” ${ }^{18}$. Jednocześnie należy podkreślić, że odwołanie całego zarządu spółki wodnej nie skutkuje nie-

\footnotetext{
15 D. Pikor, op.cit.

16 Dz. U. z 2008r. Nr 133, poz. 848, z późn. zm.

17 www.lir.lublin.pl/download/20130730spolkiwodne.pdf (dostęp: 10.03.2016 r.).

18 B. Rakoczy, Prawo..., op. cit., s. 701.
} 
Arkadiusz Jąkalski - Tworzenie spółek wodnych...

możnością wejścia członka zarządu ponownie do nowo powołanego zarządu.

Jak już wspomniano organem spółki, który reprezentuje spółkę na zewnątrz jest zarząd spółki. On też jest organem władnym do zaciągania zobowiązań oraz prowadzenia gospodarki finansowej. Więc to zarząd jako organ odpowiedzialny za reprezentacje odpowiada za wszelkie zobowiązania spółki19. Należy zauważyć, że ustawodawca dał zarządowi kompetencje w zakresie gospodarowania całym majątkiem spółki. Daje to więc faktyczne uprawnienia do podejmowania decyzji o charakterze prawnym i faktycznym ${ }^{20}$. Istnieje wiec ewidentne domniemanie, że to właśnie zarząd na podstawie swoich kompetencji odpowiada za zobowiązania spółki21.

\section{Problemy praktyczne związane z tworzeniem spółek wodnych}

Ogromnym problemem przy powoływaniu do życia spółki wodnej jest kwestia członkostwa w niej poszczególnych osób lub instytucji. Bardzo często członkowie spółki wodnej zalegające z płatnościami składek na rzecz spółki podnoszą przed sądami zarzut, że owo członkostwo nabyli bez swojej wiedzy. Dodatkowo zgłaszają także fakt, iż w spółce ich uprawnienia są często iluzoryczne ${ }^{22}$. W świetle orzeczenia Sądu Najwyższego z 29 czerwca 2010 r. ${ }^{23}$ statut spółki wodnej nie może ograniczać uprawnienia członka do wystąpienia ze spółki. Chodzi również o sytuację, w której członkostwo w spółce powstało ex lege na podstawie art. 165 ust. 7 ustawy prawo wodne Sąd Najwyższy podkreślił, że dobrowolność członkostwa oznacza zarówno swobodę przystąpienia do zrzeszenia, jak i wystąpienia z niego.

\footnotetext{
19 Ibid., s. 706.

20 Wyrok z dnia 28 maja 208 roku w Lublinie II SA/Lu 187/08 (LEX nr 524063).

${ }^{21}$ K. Kierzkowska, Rozwiq̨zanie spółki wodnym w prawie polskim, „Przegląd Prawa Ochrony Środowiska" 2012, Nr 2.

${ }^{22}$ Interpelacja $\mathrm{nr} 15552$ do ministra środowiska w sprawie funkcjonowania spółek wodnych oraz praw i obowiązków ich członków.

${ }^{23}$ Sygnatura akt III CZP/46/10 (OSNC 2011, nr 2, poz.18).
} 
Następca prawny członka spółki staje się zgodnie z prawem członkiem tejże spółki. Oznacza to, że członkostwo następcy w spółce wodnej jest identyczne i oparte na takich samych prawach i obowiązkach jak jego poprzednika. Według sądu następca wstępuje bowiem w jego prawa i obowiązki. Jeżeli zatem poprzednikowi przysługiwało uprawnienie kształtujące do wystąpienia ze spółki, to przysługuje ono również następcy. W uzasadnieniu Sąd Najwyższy stwierdził m.in., że stosunek członkostwa w spółce wodnej jest stosunkiem cywilnoprawnym mimo nadzoru i kontroli sprawowanej przez starostę nad działalnością spółek. Postanowienie statutu spółki wodnej wymagające zgody walnego zgromadzenia na wystąpienie członka w istocie prowadzi do powstania przymusowego członkostwa w sytuacji, w której zgodnie z prawem wodnym jest ono dobrowolne $\mathrm{z}$ wyjątkiem wynikającym z art. 168 ustawy prawo wodne. Dobrowolność członkostwa oznacza zaś zarówno swobodę przystąpienia do zrzeszenia, jak i wystąpienia z niego, również, gdy członkostwo powstało na podstawie wspomnianego art. 165 ust. 7 prawa wodnego. Można więc wnioskować, ze przymusowe członkostwo w spółce wodnej jest sprzeczne z Konstytucją RP24.

Możemy jednak zastanowić się nad sytuacją odwrotną. Jeśli art. 165 ust. 7 ustawy prawo wodne jest niezgodny z Konstytucją to możemy rozważać czy wystąpienie następcy prawnego członka spółki wodnej z tejże spółki jest zgodne z Konstytucją? Bo jak znaleźć uzasadnienie dla faktu, że często członek spółki wodnej występując ze niej zaburza funkcjonowanie dużego systemu melioracyjnego szkodząc przy tym innym. Należałoby wtedy tą część systemu „wyciąć” i oddać osobie występującej ze spółki wodnej. Jest to jednak niemożliwe.

W myśl obowiązujących przepisów prawa wodnego oraz funkcjonującego orzecznictwa, spółki wodne są zrzeszeniami dobrowolnymi.

\footnotetext{
${ }^{24}$ A. Suchoń, Członkostwo w spółce wodnej nie jest obowiq̨zkowe, „Tygodnik Poradnik Rolniczy", http://www.tygodnik-rolniczy.pl/articles/prawo/czlonkostwo-w-spol ce-wodnej-nie-jest-obowiazkowe/ (dostęp: 18.03.2016 r.).
} 
Arkadiusz Jąkalski - Tworzenie spółek wodnych...

W związku z powyższym członkostwo w nich jest dobrowolne. Wyjątek stanowi tutaj sytuacja uregulowana w art. 168 ustawy prawo wodne, kiedy to starosta na podstawie decyzji może włączyć zakład do spółki wodnej. Z członkostwem w spółce wiąże się natomiast obowiązek uiszczania składek, czy też innych świadczeń, jeśli tak stanowią statuty spółek wodnych.

Osoby stające się następcami prawnymi członków spółki, o których mowa w art. 165 ust. 7 ustawy, które wstępują w prawa i obowiązki swego poprzednika, mają również prawo korzystać ze swoich swobód obywatelskich. Przysługuje im prawo do wystąpienia ze spółki na podstawie złożonego oświadczenia woli. Dobrowolność członkostwa obejmuje, jak już wcześniej wskazano, także sytuację, gdy członkostwo w spółce powstało na mocy samego prawa - w drodze następstwa prawnego. Niezależnie zatem od tego, w jakiej formie dany mieszkaniec nabył członkostwo w spółce, do jego wystąpienia wystarczające powinno być oświadczenie woli o wystąpieniu. W przypadku gdy ustalone w statucie reguły wystąpienia ze spółki określone zostałyby sprzecznie z obowiązującym prawem, podmiot, którego sprawa dotyczy, ma uprawnienie zaskarżyć niezgodne z prawem uchwały w drodze sądowej.

Tak naprawdę można się spierać co do dobrowolności przynależności do spółki wodnej. Art. 30 i 31 ust. 1 i 2 Konstytucji RP stanowią, że:

1) przyrodzona i niezbywalna godność człowieka stanowi źródło wolności i praw człowieka i obywatela. Jest ona nienaruszalna, a jej poszanowanie i ochrona jest obowiązkiem władz publicznych,

2) wolność człowieka podlega ochronie prawnej,

3) każdy jest obowiązany szanować wolności i prawa innych. Nikogo nie wolno zmuszać do czynienia tego, czego prawo mu nie nakazuje.

Jednocześnie art. 31 ust. 4 Konstytucji przewiduje ograniczenia w zakresie korzystania z konstytucyjnych wolności i praw mogą być 
ustanawiane tylko w ustawie i tylko wtedy, gdy są konieczne w demokratycznym państwie dla jego bezpieczeństwa lub porządku publicznego, bądź dla ochrony środowiska, zdrowia i moralności publicznej, albo wolności i praw innych osób. Ograniczenia te nie mogą naruszać istoty wolności i praw. Czy sprawne działanie spółek wodnych nie jest aby sytuacją gdzie należałoby te prawa ograniczyć ponieważ brak efektywnych działań spółek wodnych jest dużym zagrożeniem dla naszego środowiska naturalnego? Według mnie tak. Ponieważ to właśnie działania spółek wodnych $\mathrm{w}$ dużej mierze przyczyniają się do naszego bezpieczeństwa przeciwpowodziowego. To jak spółki działają to odrębna sprawa. To kto zasiada we władzach spółki zależy od jej członków. Jeśli wybierzemy człowieka bez umiejętności daru współpracy z innymi i siły przebicia jego, działania będą żadne. Jeśli wybierzemy człowieka, który potrafi myśleć i działać jego działania będą przynosiły efekty.

Drugim bardzo istotnym problemem z którym borykają się spółki wodne jest egzekucja świadczeń i składek. Zgodnie z art. 170 ust. 5 do egzekucji składek i świadczeń, na rzecz spółki wodnej stosuje się przepisy o egzekucji należności podatkowych. Nie jest to jednak tak oczywiste w praktyce. Stało się tak na skutek postanowienia Sądu Najwyższego z dnia 11 sierpnia 2004r. w którym uznano, że przewidziana w prawie wodnym składka członkowska ma charakter świadczenia cywilnoprawnego i poddanie jej egzekucji administracyjnej nie pozbawia jej tego charakteru ${ }^{25}$. Kierując się wskazaniami wynikającymi ze wspomnianego wyroku, urzędy skarbowe zaczęły odmawiać przyjmowania tytułów wykonawczych od spółek wodnych. W analogicznej sprawie wypowiedział się Trybunał Konstytucyjny w wyroku z dnia 10 lipca 2006r.26, w odniesieniu do opłat za nielegalne pobranie paliw i energii w sieci, których możliwość dochodzenia w trybie egzekucji administracyjnej wynika z art. 57 ustawy z dnia 10 kwietnia

25 Postanowienie SN z dnia 11 sierpnia 2004 roku, II CK 481/03 (LEX nr 271669).

${ }^{26}$ Wyrok TK z dnia 10 lipca 2006 r., sygn. akt K 37/04, http://trybunal.gov.pl (dostęp: 15.02.2017 r.). 
Arkadiusz Jąkalski - Tworzenie spółek wodnych...

1997 r. Prawo energetyczne27. W uzasadnieniu tego wyroku wskazano, że należność pieniężna przedsiębiorstwa energetycznego z tytułu pobierania opłat za nielegalne pobieranie paliwa lub energii jest przekazana do egzekucji administracyjnej na podstawie art. 57 ust. 2 prawa energetycznego, jeżeli wynika ona $\mathrm{z}$ wyroku sądowego rozstrzygającego spór z odbiorcą. Dodatkowo Trybunał Konstytucyjny, postanowieniem z dnia 28 lutego 2007r.28, zasygnalizował Sejmowi potrzebę podjęcia inicjatywy ustawodawczej $\mathrm{w}$ przedmiocie pobierania przez przedsiębiorstwa energetyczne opłat za nielegalne pobieranie paliw lub energii $\mathrm{z}$ sieci oraz ich ściągania $\mathrm{w}$ drodze postępowania egzekucyjnego $\mathrm{w}$ administracji, $\mathrm{w}$ uzasadnieniu podnosząc potrzebę takiego zredagowania odpowiednich przepisów prawa energetycznego, aby wynikało z nich jednoznacznie, że przedsiębiorstwo energetyczne może pobierać opłaty za nielegalnie pobrane paliwo lub energię w wysokości określonej w taryfach wówczas, gdy odbiorca nie kwestionuje roszczenia przedsiębiorstwa. W sytuacji, gdy odbiorca odmawia uiszczenia ww. opłat, przedsiębiorstwo, celem zaspokojenia swojego roszczenia, winno skierować sprawę na drogę sądowego postępowania rozpoznawczego ${ }^{29}$.

Natomiast Naczelny Sąd Administracyjny w swoim wyroku z dnia 4 listopada 2009 r. uznał, że z przepisu art. 170 ust. 5 prawa wodnego w związku z art. $2 \S 1$ pkt 5 ustawy o postępowaniu egzekucyjnym w administracji z dnia 17 czerwca 1966 r.30 nie można wyprowadzić normy prawnej zwalniającej spółkę wodną, jako wierzyciela, od przewidzianych na zasadach ogólnych obowiązków w zakresie wymogów, jakim powinien odpowiadać tytuł wykonawczy, a w szczególności wskazania treści podlegającego egzekucji obowiązku wynikającego

27 Dz. U. Nr 89 z 2006 roku, poz. 625 z póź. zm..

28 Postanowienie Trybunału Konstytucyjnego z dnia 28 lutego 2007 r., sygn. akt S 3/07; http://prawo.money.pl/orzecznictwo/trybunal-konstytucyjny/postanowie nie;z;dnia;2007-02-28,s,3,07,3413,orzeczenie.html (dostęp: 15.0.2017r.).

29 Odpowiedź podsekretarza stanu w Ministerstwie Finansów - z upoważnienia ministra - na interpelację nr 4659 w sprawie egzekucji administracyjnej należności pieniężnych, o których mowa w art. 170 ustawy Prawo wodne.

30 Tekst jednolity Dz. U. z 2016 r. poz. 599 z późn. zm. 
z odpowiedniej decyzji lub wyroku sądowego, stosownie do przepisu art. $27 \S 1$ pkt 3 ustawy o postępowaniu egzekucyjnym w administracji. Spółka wodna, jako wierzyciel, nie jest w tym zakresie podmiotem uprzywilejowanym ${ }^{31}$.

Pojawia się $\mathrm{w}$ tym miejscu pytanie: czy urzędy skarbowe mogą wstrzymać egzekwowanie tytułów wykonawczych związanych z nieuiszczaniem składek za konserwację urządzeń melioracyjnych przez członków spółki wodnej bez uzyskanie prze tą, spółkę wyroku sądowego? Jak wyżej zostało wspomniane, zgodnie z art. $170 \S 1$ ustawy prawa wodnego członek spółki wodnej jest obowiązany do wnoszenia składek i ponoszenia na jej rzecz innych określonych w statucie świadczeń niezbędnych do wykonywania statutowych zadań spółki. W przypadku niewykonania tego obowiązku możliwe jest dochodzenie należności pieniężnych z majątku członka spółki wodnej w trybie egzekucji administracyjnej. Okazuje się jednak, że przekazanie do egzekucji administracyjnej tych należności nie jest jednak wystarczającą podstawą do wszczęcia i prowadzenia egzekucji administracyjnej. Możliwość takiego postępowania została uzależniona od spełnienia drugiego warunku określonego $\mathrm{w}$ art. 4 ustawy o postępowaniu egzekucyjnym w administracji - uzyskania przez wierzyciela stosownego orzeczenia sądu. Zatem podstawą prawną dochodzonego obowiązku może musi być prawomocne orzeczenie sądu, z którego wynika istnienie obowiązku uiszczenia składki członkowskiej ${ }^{32}$.

\section{Podsumowanie}

Należy stwierdzić, że spółki wodne są organizacjami mającymi olbrzymie znaczenie dla rolnictwa i gospodarki wodnej. Borykają się

31 Wyrok Naczelnego Sądu Administracyjnego z dnia 4 listopada 2009 r II GSK 557/09 dostępny na stronie internetowej http://www.lexlege.pl/orzeczenie/141883 /ii-gsk-557-09-wyrok-naczelnego-sadu-administracyjnego/ (dostęp: 15.02.2017 r.).

32 Wyrok Naczelnego Sądu Administracyjnego z dnia 4 listopada 2009 r II GSK 557/09; http://www.lexlege.pl/orzeczenie/141883/ii-gsk-557-09-wyrok-naczelnego -sadu-administracyjnego/ (dostęp: 15.02.2017 r.). 
Arkadiusz Jąkalski - Tworzenie spółek wodnych...

z problemami jakimi jest członkostwo poszczególnych członków oraz ściągalność składek członkowskich. Potrzebne są zmiany prawa w tym zakresie, które dały by większe umocowania prawne zarządom spółek w zakresie egzekucji oraz członkostwa. Tym czasem przyszłość spółek wodnych w świetle proponowanych zmian ustawy prawy wodne jest bardzo niepewna ponieważ zmiany jakie mogą zajść pozbawią te organizacje środków pieniężnych na finansowanie swojej działalności a sama spółka zostanie zepchnięta do roli organu pomocniczego gminy.

\section{Bibliografia:}

Kierzkowska K., Rozwiq̨zanie spółki wodnym w prawie polskim, „Przegląd Prawa Ochrony Środowiska" 2012, Nr 2.

Opaliński Ł, Melioracje - aspekty prawne -opracowanie, Wrocław 2013.

Paczuski R., Spótki wodne, historia, podstawy prawne działania, nowe tendencje, Warszawa 1989.

Paczuski R., Spótki wodne - cele, zadania, prawne podstawy organizacji oraz perspektywy ich rozwoju w kontekście zachodzących zmian, Toruń 2006,

Pikor D., Tworzenie spótek wodnych, http://www.naukaibiznes.tv/artykuly/ pokaz/ tworzenie-spolek-wodnich.

Rakoczy B., Prawo wodne - Komentarz, Warszawa 2013.

Rakoczy B., Wybrane problemy prawa wodnego, Warszawa 2013.

Szachułowicz J., Prawo wodne, komentarz, Warszawa 2010.

Suchoń A., Członkostwo w spółce wodnej nie jest obowiq̨zkowe, [w:] „Tygodnik Poradnik Rolniczy", http://www.tygodnik-rolniczy.pl/articles/prawo/ czlonkostwo-w-spolce-wodnej-nie-jest-obowiazkowe.

\section{Źródła internetowe:}

http://www.lir.lublin.pl/download/20130730spolkiwodne.pdf http://www.srodowisko.abc.com.pl/czytaj/-/artykul/tworzenie-spolekwodnych 